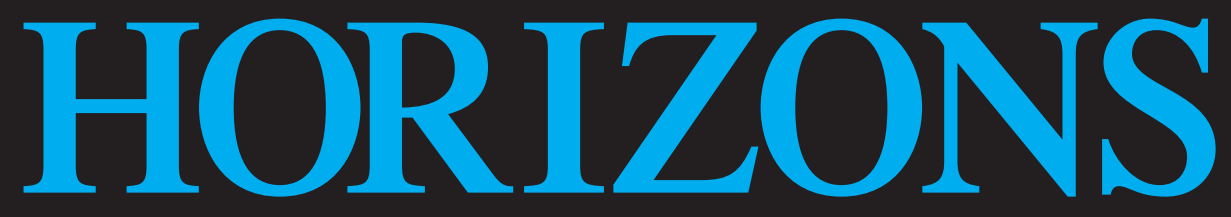

Volume 28

Fall, 2001

Number 2

ARTICLES

Philip F. Sheldrake, Practicing Catholic "Place"-The Eucharist

Christine E. Gudorf, Resymbolizing Life: Religion on Population and Environment

Patricia Ann Lamoureux, Justice for Wage Earners

Diana L. Villegas, Personal Engagement: Constructive Source of Knowledge or Problem for Scholarship in Christian Spirituality?

\title{
EDITORIAL ESSAYS
}

Paul F. Knitter, Commitment to One-Openness to Others

John D'Arcy May, Catholic Fundamentalism? Some Implications of Dominus Iesus for Dialogue and Peacemaking

Edmund Chia, F.S.C., Of Fork and Spoon or Fingers and Chopsticks: Interreligious Dialogue in Ecclesia in Asia

\section{BIBLIOGRAPHY}

Thomas W. O'Brien, Bibliography of Charles E. Curran, 1990-2000: Another Decade of Catholic Moral Theology

\section{REPORT OF THE COLLEGE THEOLOGY SOCIETY}

\section{REVIEW SYMPOSIUM}

Michael Horace Barnes' Stages of Thought: The Co-Evolution of Religious Thought and Science

Four Perspectives: Thomas B. Ommen, Donna Teevan, William Cenkner, Mary Frohlich

Author's Response: Michael Horace Barnes

Plus Reviews of 26 Books 


\section{PATHS TO UINDERSTANDING}

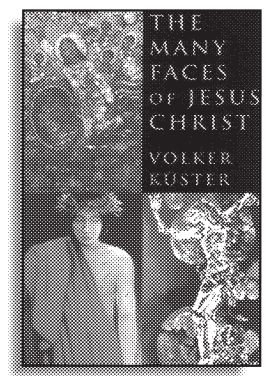

Volker Küster

The Many Faces of Jesus Christ

Intercultural Christology

How the images of Jesus as the Christ in various cultural contexts of the world constitute a challenging opportunity for ecumenical learning and a visionary path of healing.

1-57075-354-7 Paperback \$25.00

Whalen Lai and Michael von Brück

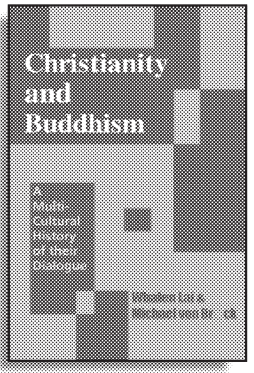

\section{Christianity and Buddhism}

A Multi-Cultural History of Their Dialogue

This complete survey of Buddhist-Christian dialogue points to key areas of progress and understanding, as well as to problem areas where dialogue needs to develop.

1-57075-362-8 Paperback $\$ 40.00$

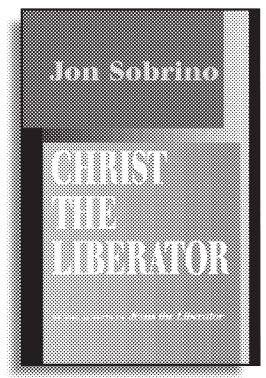

\section{Jon Sobrino}

\section{Christ the Liberator}

A View from the Victims

Jon Sobrino continues the magisterial christology begun in Jesus the Liberator. In this second volume he takes up the Resurrection of Christ, the christology of the New Testament, and the christological formulae of the early church councils.

1-57075-372-5 Paperback \$28.00

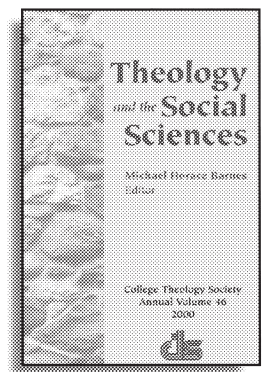

Michael Horace Barnes, Editor

Theology and the Social Sciences

The College Theology Society Annual, Vol. 46

Original essays demonstrate how sociology, history, anthropology, and psychology all leave their mark on theology and open rich new paths to understanding.

1-57075-355-5 Paperback \$20.00 


\title{
HORIZONS
}

\section{The Journal of the College Theology Society}

\author{
Published at Villanova University
}

Volume 28

Fall, 2001

Number 2

\section{ARTICLES}

Practicing Catholic "Place"-

The Eucharist

Philip F. Sheldrake 163

Resymbolizing Life: Religion on Population and Environment Christine E. Gudorf 183

Justice for Wage Earners: Retrieving Insights from

the Catholic Community

Personal Engagement: Constructive Source of

Knowledge or Problem for Scholarship in

Christian Spirituality?

Diana L. Villegas

\section{EDITORIAL ESSAYS}

Commitment to One-Openness to Others:

A Challenge for Christians Paul F. Knitter

Catholic Fundamentalism? Some Implications of Dominus Iesus for Dialogue and Peacemaking John D’Arcy May

Of Fork and Spoon or Fingers and Chopsticks: Interreligious Dialogue in Ecclesia in Asia ..... Edmund Chia, F.S.C. 294

\section{BIBLIOGRAPHY}

Bibliography of Charles E. Curran, 1990-2000:

Another Decade of Catholic Moral Theology ..... Thomas W. O'Brien 307

REPORT OF THE COLLEGE THEOLOGY SOCIETY ........................ 314

\section{REVIEW SYMPOSIUM}

Michael Horace Barnes' Stages of Thought:

The Co-Evolution of Religious Thought and Science

Four Perspectives Thomas B. Ommen 


\section{BOOK REVIEWS}

John S. Dunne, Reading the Gospel George R. Haynes

Pamela Bright, ed., Augustine and the Bible Thomas F. Martin, O.S.A. 336

Elizabeth A. Dreyer, ed., The Cross in Christian

Tradition: From Paul to Bonaventure Joan Mueller 338

Robert Boenig, trans., Anglo-Saxon Spirituality:

Selected Writings Lawrence S. Cunningham

Adrian House, Francis of Assisi:

A Revolutionary Life Daniel Van Slyke

Zachary Hayes, Bonaventure:

Mystical Writings John V. Apczynski

John Henry Newman, Lectures on the Present

Position of Catholics in England; Fathers of Birmingham

Oratory, eds., Sermon Notes of John Henry Newman

1849-1878; John Henry Newman, Callista: A Tale of the

Third Century Walter E. Conn

David G. Kamitsuka, Theology and Contemporary

Culture: Liberation, Postliberal and Revisionary Perspectives Richard Viladesau

Pierre Hegy and Joseph Martos, eds., Catholic

Divorce: The Deception of Annulments William P. Roberts

Wendy M. Wright, Sacred Heart: Gateway to God Lawrence S. Cunningham

William Johnston, “Arise, My Love ....”: Mysticism for a New Era Mary Frohlich

Wilkie Au, The Enduring Heart: Spirituality for the Long Haul Carla Mae Streeter, O.P. Joseph B. Allegretti, Loving Your Job, Finding

Your Passion: Work and the Spiritual Life Kathleen Fischer, Transforming Fire: Women Gwen Laurie Wright

Using Anger Creatively; Thomas Hart, Spiritual Quest:

A Guide to the Changing Landscape Wendy M. Wright

James Keating, ed., Spirituality and Moral

Theology: Essays from a Pastoral Perspective Matthew Baasten

Linda Hogan, Confronting the Truth: Conscience in the Catholic Tradition David P. Schultz, F.S.C. 352

Patricia Beattie Jung, ed., Good Sex: Feminist

Perspectives from the World's Religions Margot Stevenson

Mark Lewis Taylor, The Executed God: The Way of the Cross in Lockdown America Anthony J. Tambasco 355

David Ray Griffin, Religion and Scientific

Naturalism: Overcoming the Conflicts Michael H. Barnes 356

Roger Arnaldez, Averroës: A Rationalist in Islam David B. Burrell, C.S.C. 358 
Judson B. Trapnell, Bede Griffiths: A Life in Dialogue

John C. Raines and Daniel C. Maguire, eds., What Men Owe to Women: Men's Voices from World Religions Leonard J. Biallas 360

Ellen T. Armour, Deconstruction, Feminist Theology, and the Problem of Difference:

Subverting the Race/Gender Divide Winifred Whelan 361

BOOKS RECEIVED 363

INDEX 370

Copyright @ 2001 College Theology Society

Printed in the United States of America 


\section{HORIZONS}

\section{The Journal of the College Theology Society}

Horizons, The Journal of the College Theology Society is published biannually in Spring and Fall at Villanova University, Villanova, PA 19085.

Yearly subscription: individual \$16.00, institutional \$40.00. Send remittance, payable to CSSR, to CSSR Executive Office, Valparaiso University, Valparaiso, IN 46383. Changes of address should also be sent to this address. Horizons is automatically received through membership in the College Theology Society.

Manuscripts, editorial and business correspondence, book reviews, advertising copy, and orders for single issues (individual $\$ 8.00$, institutional \$20.00) should be addressed to The Editor, Horizons, Journal of the CTS, Villanova University, Villanova, PA 19085. Telephone: (610) 519-7302. E-mail: HORIZONS@VILLANOVA.EDU

In submitting manuscripts, please send four clear copies. Author's name should appear only on an unpaginated cover sheet, with address and essay's title. No other identifying reference to author should appear on the manuscript. All references to author's work in text or notes should be in the third person. Essay's title should appear at top of first page of text. Notes should be placed on separate sheets at end. Full double spacing should be used throughout, including indented quotations and notes. Top, bottom, and right-hand margins should be at least one inch; left-hand margins at least one-and-a-half. Manuscripts should be accompanied by an abstract of one hundred fifty words or less and an author vita of one hundred words or less. Authors should state that the manuscript will not be submitted to another journal until Horizons' evaluation is completed. Manuscripts will be returned if postage is supplied.

Articles appearing in Horizons are abstracted and indexed in: The Catholic Periodical and Literature Index; Guide to Social Science and Religion in Periodical Literature; Index to Religious Periodical Literature; New Testament Abstracts; Religious and Theological Abstracts; and Social Science Citation Index. Articles are indexed in Religion Index One: Periodicals; book reviews indexed in Index to Book Reviews in Religion. Horizons is available in microform from Bell \& Howell, 300 North Zeeb Road, P.O. Box 1346, Ann Arbor, MI 48106-1346. It is also available on line in full text to ATLAS subscribers.

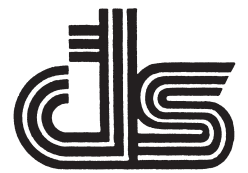

\section{COLLEGE THEOLOGY SOCIETY}

The College Theology Society is a professional organization of college and university professors of religion in the United States and Canada.

The purpose of the College Theology Society is to improve the quality of the teaching of religion: by stimulating and sharing scholarly research; by developing programs of theology and religious studies which meet student needs and interests; and by exploring, evaluating, and encouraging effective ways of teaching which are interdisciplinary and ecumenical.

Annual membership dues in the Society are $\$ 40.00$ (Full Professional or Associate), \$45.00 (Joint Professional for husband and wife), and \$20.00 (Graduate Student). Membership in the Society includes a subscription to Horizons. Contact Alexis Doval, St. Mary's College, Box 5150, Moraga, CA 94575. Telephone: (925) 631-4403. E-mail: adoval@stmarys-ca.edu 


\section{EDITOR}

Walter E. Conn

Villanova University

\section{ASSOCIATE EDITORS}

Lisa Sowle Cahill

Boston College

Denise Lardner Carmody

Santa Clara University

Anne Carr

University of Chicago

Bernard Cooke

College of the Holy Cross (Emeritus)

Lawrence S. Cunningham

University of Notre Dame

Charles E. Curran

Southern Methodist University

Margaret A. Farley

Yale Divinity School

Elisabeth Schüssler Fiorenza

Harvard Divinity School

Francis Schüssler Fiorenza

Harvard Divinity School
Mary Ann Hinsdale Boston College

Elizabeth A. Johnson

Fordham University

Paul F. Knitter

Xavier University

Pheme Perkins

Boston College
Sandra M. Schneiders, I.H.M. Jesuit School of Theology at Berkeley

William M. Shea

Saint Louis University

Gerard S. Sloyan

Temple University (Emeritus)

William M. Thompson

Duquesne University

David W. Tracy

University of Chicago

Mary Jo Weaver

Indiana University

BOOK REVIEW EDITOR

Joann Wolski Conn

Neumann College

BUSINESS EDITOR

Anne McGuire

Haverford College

EDITORIAL ASSISTANT

Irene C. Noble 


\section{Horizons}

\section{The Journal of the College Theology Society}

A journal exploring developments in Catholic theology, the total Christian tradition, human religious experience, and the concerns of creative teaching from the college and university environment.

We have an exciting mix of topics, disciplines, and perspectives in this issue. Philip Sheldrake leads off our Articles with his reflections on "Practicing Catholic 'Place'-The Eucharist." Christine Gudorf follows with her view on one of our most difficult societal problems: "Resymbolizing Life: Religion on Population and Environment." Patricia Lamoureux turns to Catholic sources as she takes on once again one of our most persistent ethical issues: "Justice for Wage Earners.” Diana Villegas addresses a key methodological question in the academic study of Christian Spirituality: do we have a source of knowledge or a problem in "Personal Engagement"?

A theme should emerge easily as you move through our Editorial Essays. Paul Knitter sets a context with his "Commitment to OneOpenness to Others: A Challenge for Christians.” John May then examines "Catholic Fundamentalism? Some Implications of Dominus Jesus for Dialogue and Peacemaking." And Edmund Chia considers interreligious dialogue in Ecclesia in Asia in "Of Fork and Spoon or Fingers and Chopsticks."

Thomas O'Brien closes out the century by adding another decade to the "Bibliography of Charles E. Curran" he first compiled for Horizons in Fall, 1991. For the record, Felicidad Oberholtzer reviews the highlights of this year's CTS National Meeting. Michael Barnes responds to the comments of Thomas Ommen, Donna Teevan, William Cenkner, and Mary Frohlich on his Stages of Thought: The CoEvolution of Religious Thought and Science. Reviews of twenty-six new books complete our issue.

Your humble Editor and Book Review Editor are most grateful to the CTS President, Board of Directors, and membership for the CTS Presidential Award. 